\section{Crop Injury from Sublethal Rates of Herbicide. III. Pepper}

\author{
James P. Gilreath ${ }^{2}$ \\ Gulf Coast Research and Education Center, University of Florida, \\ Bradenton, FL 34203
}

\author{
Carlene A. Chase and Salvadore J. Locascio \\ Horticultural Sciences Department, University of Florida, Gainesville, \\ FL 32611-0690
}

Additional index words. spray drift, herbicide injury, flower abscission, Capsicum annuиm

\begin{abstract}
Sublethal rates of 2,4-D and dicamba were applied to pepper to evaluate the possible effects of single or multiple exposures to drift from these herbicides. Dicamba induced more foliar injury than did 2,4-D and reduced vigor more as herbicide rates increased. Postbloom applications reduced vigor less than did earlier applications. Epinastic response was affected by stage of development at application and time after treatment. Postbloom applications did not affect yield, but dicamba and 2,4-D applied at earlier stages of development resulted in linear reduction of marketable and total yields as rates increased to $112 \mathrm{~g} \cdot \mathrm{ha}^{-1}$. Reductions in plant vigor with increased rates were greater and foliar epinasty was more pronounced with two sequential applications of 2,4-D or dicamba than with single applications. Marketable yields were unaffected by single prebloom applications but declined linearly with two applications. Cull and total yields were not affected by the number of applications. With prebloom and bloom applications of 2,4-D, flower abscission increased and fruit set decreased as rate increased. Chemical names used: 3,6-dichloro-2-methoxybenzoic acid (dicamba); 2,4- dichlorophenoxy)acetic acid (2,4-D).
\end{abstract}

Dicamba and 2,4-D selectively control broadleaf weeds in grass crops. In sensitive plants, these auxin-like herbicides stimulate ethylene formation (Abeles, 1968). Phytotoxicity results from the accumulation of cyanide, a coproduct of ethylene synthesis (Tittle et al., 1990). In Florida, both 2,4-D and dicamba are registered for broadleaf weed control in corn (Zea mays L.), sorghum (Sorghum bicolor L. Moench), small grains, turf, pasture and rangeland. Spray and vapor drift of auxinic herbicides can be damaging to nontarget broadleaf crops. The use of 2,4-D along roadways during windy conditions has resulted in damage to crops in adjacent fields (Gilreath, personal observation).

Spraying with sublethal concentrations is a commonly used technique to evaluate the possible effects of herbicidal drift. In assessing the effects of sublethal rates of dicamba on potato (Solanum tuberosum L.), foliar injury and stunting were reported with rates of 2.8 to $22.2 \mathrm{~g} \cdot \mathrm{ha}^{-1}$, and total and marketable yields were reduced (Wall, 1994). Similar work on tomato (Lycopersicon esculentum Mill.) has been focused primarily on the effects of 2,4-D vapor drift, with fewer reports of spray drift

\footnotetext{
Received for publication 13 Apr. 2000. Accepted for publication 12 Oct. 2000. Florida Agricultural Experiment Station Journal Series No. R-07748. The cost of publishing this paper was defrayed in part by the payment of page charges. Under postal regulations, this paper therefore must be hereby marked advertisement solely to indicate this fact.

${ }^{1}$ To whom requests for reprints should be addressed. E-mail address: DrGilreath@aol.com
}

that of Hemphill and Montgomery (1981) by examining the more commonly cultivated $C$. annuиm, evaluating the effects of multiple exposures, comparing the effects of two herbicides, and using the polyethylene-mulch production system commonly used for pepper production.

\section{Materials and Methods}

Three field experiments were conducted at the Gulf Coast Research and Education Center in Bradenton, Fla., on a subsurface-irrigated EauGallie fine sand (sandy, siliceous, hyperthermic, Alfic Haplaquod) soil.

Expt. 1. Thirty-seven 'Mercury' pepper transplants were set $20.3 \mathrm{~cm}$ apart on polyethylene-mulched, raised beds $0.76 \mathrm{~m}$ wide. Plots consisted of single rows $7.52 \mathrm{~m}$ long $\times$ $1.37 \mathrm{~m}$ wide with $1.62-\mathrm{m}$-long alleys and were separated by a guard row or a drainage ditch of equal width. The experiment was laid out as a randomized block design with six replications. The factorial arrangement of treatments compared two herbicides-dicamba (Banvel $^{\circledR} 4$ EC; BASF, Research Triangle Park, N.C.) and 2,4-D amine (DMA ${ }^{\circledR} 4$; Dow AgroSciences, Indianapolis), each applied at $0,0.11,1.12,11.2$, and $112 \mathrm{~g} \cdot \mathrm{ha}^{-1}$ at bloom when crown blooms had just opened, or postbloom when crown fruit had attained a diameter of 2.5 to $4.4 \mathrm{~cm}$. Plant vigor and leaf epinasty were rated from low to high on a scale from 0 to 10 ; a rating of 0 indicated dead plants or no epinasty. Fruits were harvested from 25 plants per plot on 29 Oct. and 17 Nov., then separated into marketable and cull categories and weighed.

Expt. 2. The effects of single and double exposures on 'Mercury' pepper plants of sublethal levels of 2,4-D or dicamba were evaluated in Spring 1987. Twenty pepper plants were transplanted $30.5 \mathrm{~cm}$ apart on $26 \mathrm{Feb}$. Plots were $6.1 \times 1.37 \mathrm{~m}$ and were separated by 5.49-m alleys along the beds with two guard rows between plots. Two plants at the end of each plot were used as a guard row, so that data were collected for 16 of the 20 plants. Dicamba and 2,4-D were applied at rates of $0,0.11,1.12$, $11.2 \mathrm{~g} \cdot \mathrm{ha}^{-1}$ on $2 \mathrm{Apr}$., when flower buds were swollen, or as two sequential applications (each at full rate) on 2 and $13 \mathrm{Apr}$. (first fruits 1.3 to $1.9 \mathrm{~cm}$ in diameter). The experimental design was a randomized complete block with five replications. Fruits were harvested on 15 May, 3 June, and 17 June, graded, and weighed.

Expt. 3. Twenty-eight 'Early Cal Wonder' pepper plants were transplanted $20.3 \mathrm{~cm}$ apart in plots that were $5.69 \mathrm{~m}$ long $\times 1.37 \mathrm{~m}$ wide on 0.76 -m-wide polyethylene-mulched beds. Guard rows separated plots and there was a 4.06-m alley at the end of each plot. 2,4-D was applied at $0,0.11,1.12,11.2 \mathrm{~g} \cdot \mathrm{ha}^{-1}$ at three stages of development: prebloom (flower buds present), bloom, and postbloom (first fruits $4 \mathrm{~cm}$ in diameter) on 21 Mar., 29 Mar., and 15 Apr. 1988, respectively. The factorial experiment was arranged in a randomized complete block with six replications. Yield data were collected for 20 of the 28 plants per plot (the first four plants at each end 
of the plot were not harvested), and plant height, and numbers of blooms and fruit were evaluated on one plant per plot.

Data were analyzed using the GLM procedure of SAS (SAS Institute, 1988). Orthogonal polynomials were employed to examine the nature of the response to herbicide rate. Some of the yield data were logarithmically transformed to correct for heterogeneity of variance (Snedecor and Cochran, 1980).

\section{Results and Discussion}

Expt. 1. For plant vigor, interaction between herbicide and rate was significant $(P \leq$ $0.001)$. Higher order interactions between stage of development at application and time of evaluation after treatment were not significant; therefore, herbicide $\times$ rate means were pooled over developmental stage and time of evaluation. Plant vigor declined more rapidly with increasing rates of dicamba than with increasing rates of 2,4-D (Fig. 1A). Interaction between stage of development at application and rate was also significant $(P \leq 0.001)$; however, third- and fourth-order interactions

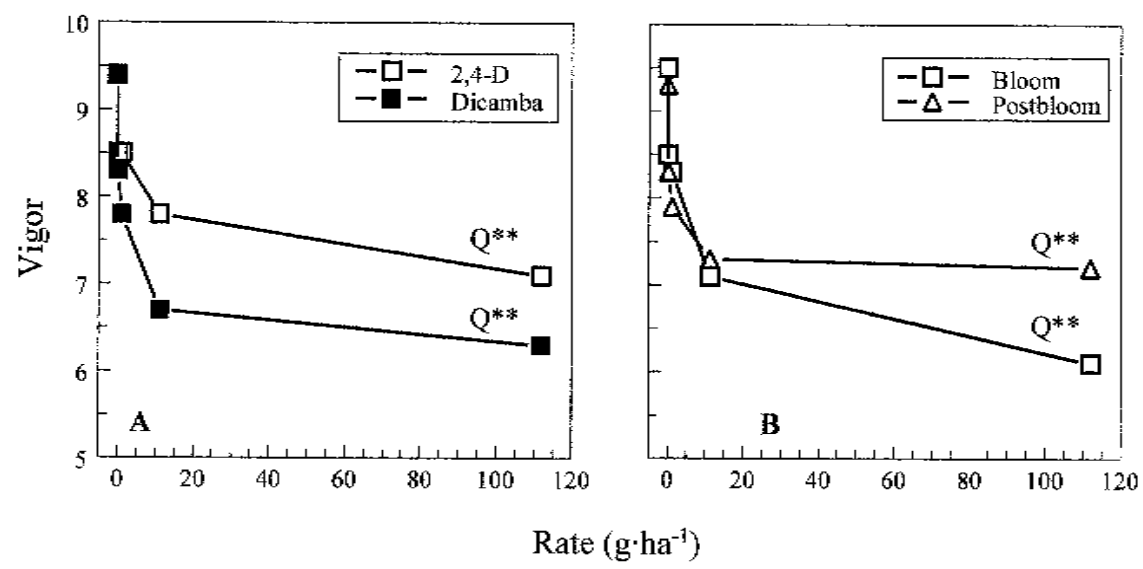

Fig. 1. Pepper plant vigor in response to (A) increasing rates of 2,4-D and dicamba averaged over stage of development at application, and (B) herbicide rate and stage of development at application averaged over herbicide (Expt. 1). *"Quadratic (Q) effects significant at $P \leq 0.01$. Vigor was rated on a scale from 0 to 10 , with 10 being the highest and 0 indicating dead plants.

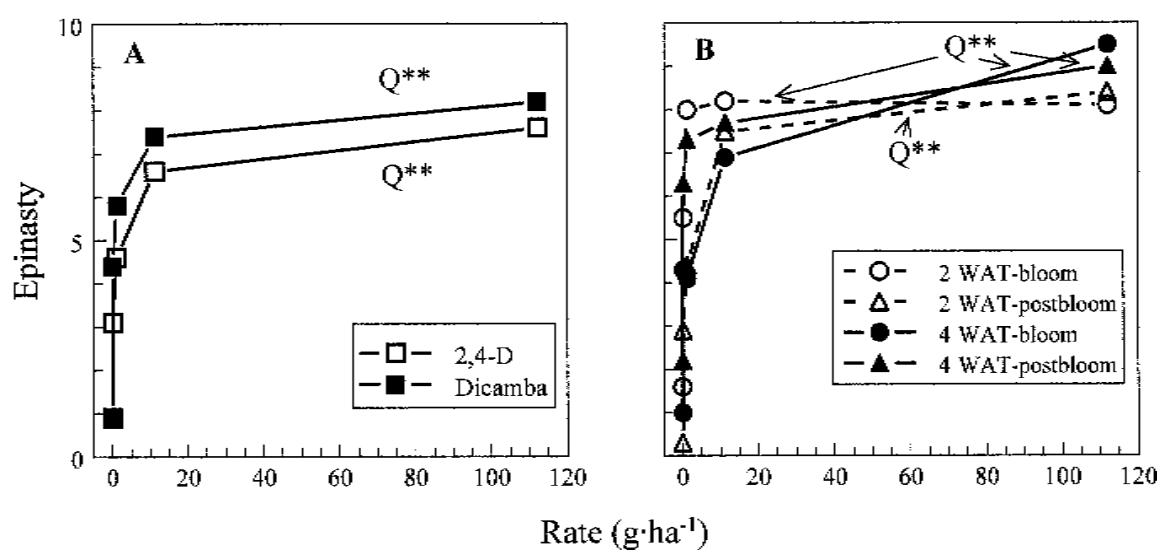

Fig. 2. Foliar epinasty in pepper in response to (A) increasing rates of 2,4-D and dicamba averaged over stage of development at application, and $(\mathbf{B})$ herbicide rate and stage of development at application averaged over herbicide (Expt. 1). ${ }^{* *}$ Quadratic $(\mathrm{Q})$ effects significant at $P \leq 0.01$. A rating of 0 to 10 was used, with 10 being the most severe epinasty and 0 indicating none. effect of herbicide rate on yields of marketable and cull fruit differed with time of application $(P \leq 0.01)$. With bloom applications, marketable yields decreased as herbicide rates increased from 0 to $112 \mathrm{~g} \cdot \mathrm{ha}^{-1}$ (Fig. 3A). However, postbloom application of 2,4-D and dicamba had no effect on marketable yield. Cull fruit increased as herbicide rate rose as high as $11.2 \mathrm{~g} \cdot \mathrm{ha}^{-1}$, then declined with the 112 $\mathrm{g} \cdot \mathrm{ha}^{-1}$ rate (Fig. 3B). An initial increase in yield of cull fruit also occurred with postbloom herbicide applications of 0.11 and $1.12 \mathrm{~g} \cdot \mathrm{ha}^{-1}$. However, the subsequent decline in yield of cull fruit with 11.2 and $112 \mathrm{~g} \cdot \mathrm{ha}^{-1}$ 2,4-D and dicamba was not as severe as with bloom applications. For total yield, interaction between developmental stage and rate was nonsignificant. Data for total yield therefore were pooled across developmental stage and a linear decline in total yield was observed with increasing herbicide rate (Fig. 3C). Averaged over rate, total yield with postbloom applications was $2 \mathrm{t} \cdot \mathrm{ha}^{-1}$ greater than with bloom applications $(P \leq 0.02$, data not shown).

Although pepper plants appeared to be more susceptible to epinasty with postbloom applications in this experiment, the decline in vigor was less than with bloom applications, while the marketable and total yields were not affected. This suggests that the significant depression of yield by sublethal rates of auxinic herbicides may be related to their effects on reproductive development. Flower abscission and reduced fruit set in pepper and tomato have been noted with exposures to such herbicides (Gilreath et al., unpublished; Hemphill and Montgomery, 1981; Orsenigo, 1964; Robbins and Taylor, 1957).

Expt. 2. Dicamba and 2,4-D affected plant vigor and induced epinasty in a similar manner, so data were pooled across herbicides. When the effects of single and double applications on vigor were compared over 4 weeks following the single or initial applications, there was significant interaction between rate and number of applications $(P \leq 0.01)$. This indicated that vigor declined more rapidly with the double applications than with single applications (Fig. 4A). Unlike plant vigor, the effects of herbicide rate and the number of herbicide applications on epinasty differed with time of evaluation after application $(P \leq$ $0.0001)$. In evaluations 2 and 4 weeks after the single or initial applications, foliar epinasty increased quadratically with increasing herbicide rate (Fig. 4B). Interaction between number of applications and rate was significant $(P \leq 0.0001)$ for both times of evaluation, indicating that epinasty increased more rapidly with sequential applications than with single applications.

The effect of rate on marketable yield varied with herbicide $(P \leq 0.01)$ and with number of applications $(P \leq 0.05)$. Marketable yield was unaffected by $2,4-\mathrm{D}$ rate, but declined linearly with increasing dicamba rates (Fig. 5A). Although marketable yield was unchanged by increasing herbicide rates when applied as single applications, double applications resulted in a significant linear reduction in marketable yield as herbicide rates increased 

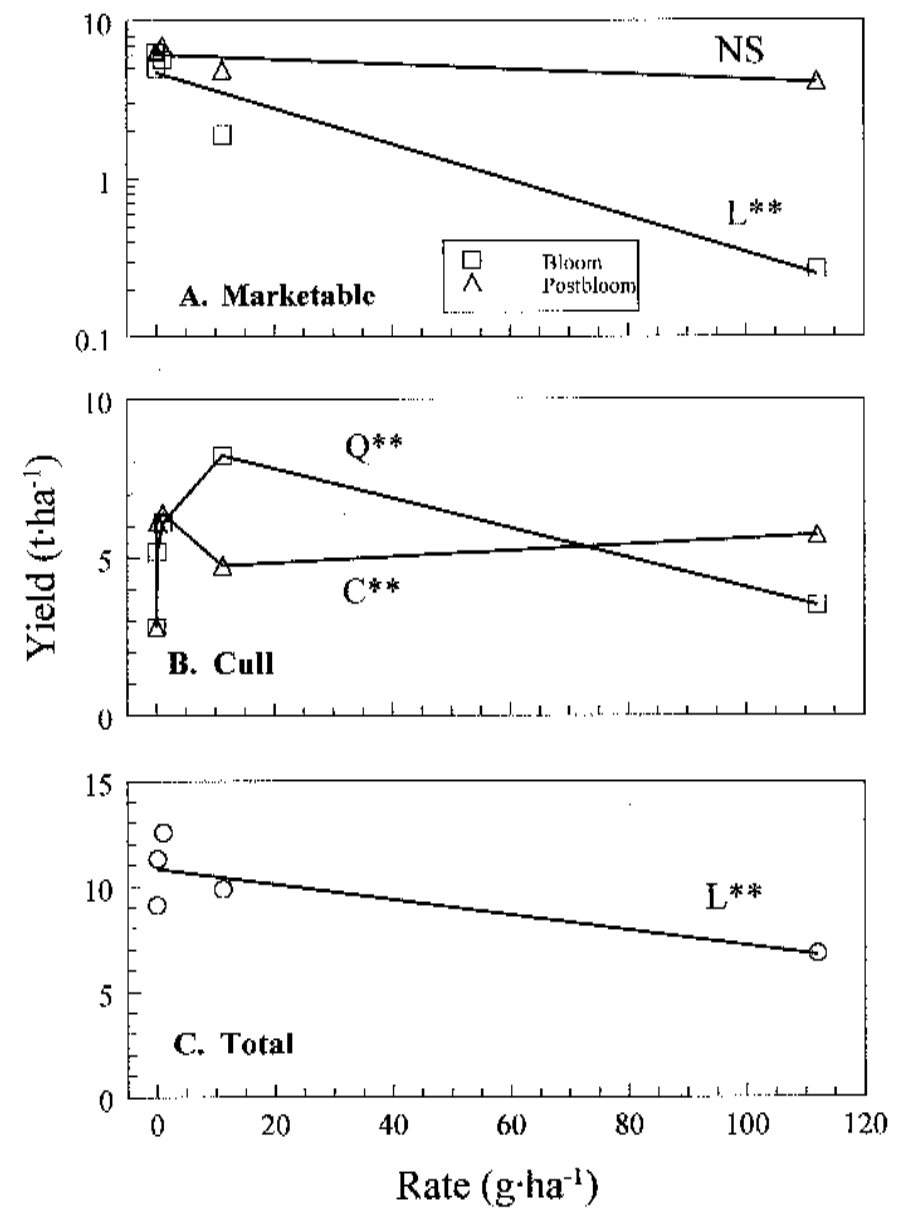

Fig. 3. (A) Marketable, (B) cull, and (C) total pepper yield in response to herbicide rate and stage of development at application (Expt. 1). Data averaged over herbicide in (A) and (B) and over herbicide and developmental stage in $(\mathbf{C})$. ${ }^{\text {ss, }{ }^{*}, * *}$ Nonsignificant and significant at $P \leq 0.05$ and $P \leq 0.01$, respectively, for linear $(\mathrm{L})$, quadratic $(\mathrm{Q})$, or cubic $(\mathrm{C})$ effects. Marketable yield was log-transformed to correct for heterogeneity of variance. Note that vertical scales differ and that scale in (A) is logarithmic.
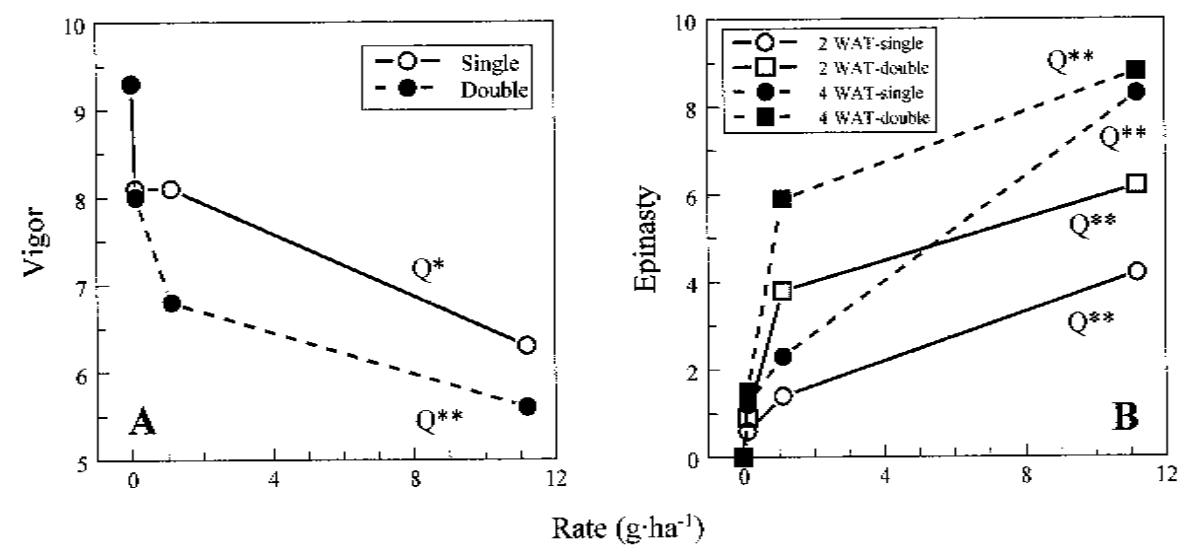

Fig. 4. Influence of single or double sprays of 2,4-D and dicamba on pepper (A) plant vigor and (B) leaf epinasty (Expt. 2). ${ }^{* * *}$ Significant at $P \leq 0.05$ and $P \leq 0.01$, respectively, for quadratic (Q) effects. Vigor was rated from 0 to 10 , with 10 being highest and 0 indicating dead plants. Rate $\times$ application means for vigor were pooled over times of evaluation. A leaf epinasty rating of 10 indicated severe epinasty and 0 indicated none. WAT indicates weeks after single/first application.

(Fig. 5B). Averaged over herbicide and number of applications, cull and total yields declined linearly with increased herbicide rates (Fig. 6). When pooled across herbicide and rate, cull yield was $85,218 \mathrm{~kg} \cdot \mathrm{ha}^{-1}$ with single herbicide applications and decreased to 71,112 $\mathrm{kg} \cdot \mathrm{ha}^{-1}$ with two sequential applications $(P \leq$
0.01; data not shown). Similarly, total fruit yield was 111,734 and $89,302 \mathrm{~kg} \cdot \mathrm{ha}^{-1}$ with single and double applications, respectively ( $P \leq 0.01$; data not shown).

Expt. 3. Plant height, averaged over rate and time of evaluation, was $28.8 \mathrm{~cm}$ with 2,4-D application at bloom, which was greater than the plant height of $22.4 \mathrm{~cm}$ obtained with prebloom application $(P \leq 0.0001$; data not shown). The response of plant height to increasing rate, pooled across developmental stage and time of evaluation, was significant ( $P \leq 0.05$; data not shown): mean plant height, which was $25.8 \mathrm{~cm}$ in untreated plants, increased to $27.4 \mathrm{~cm}$ in plants treated with 0.11 and $1.12 \mathrm{~g} \cdot \mathrm{ha}^{-1} 2,4-\mathrm{D}$ then declined to $21.9 \mathrm{~cm}$ with a further rate increase to $11.2 \mathrm{~g} \cdot \mathrm{ha}^{-1}$.

The response of plant vigor to increasing rates of 2,4-D differed with stage of development at application $(P \leq 0.0001)$. Since no interaction occurred among rate, stage, and time of evaluation, rate $\times$ stage means were pooled over time of evaluation. Postbloom applications of 2,4-D had no effect on vigor (Fig. 7A). However, vigor decline was linear with increasing rates of 2,4-D applied prebloom and at bloom. Foliar epinasty increased as herbicide rates increased, but the response differed with stage of development at application and the time of evaluation after application (Fig. 7B). Epinasty in response to 2,4-D application varied significantly with rate, developmental stage, and time of evaluation $(P \leq$ $0.0001)$. At all times of evaluation significant interaction occurred between rate and developmental stage $(P \leq 0.0001)$ and representative results are illustrated for $2 \mathrm{WAT}$ (Fig. 7B). Mild epinasty was observed with 2,4-D treatment. The response to increasing rates was quadratic and differed with developmental stage.

For both flower and fruit number per plant interaction among rate, developmental stage, and time of evaluation was significant $P \leq$ 0.05). Representative data are presented for two times of evaluation (Fig. $7 \mathrm{C}$ and D). At 2 weeks after application of 2,4-D interaction between rate and stage was significant $(P \leq$ 0.0001 ). Flowering had just begun and even nontreated plants had fewer than five flowers per plant (Fig. 7C). Flower number was not affected by prebloom application, but declined linearly from 18 (control) to one per plant with $11.2 \mathrm{~g} \cdot \mathrm{ha}^{-1}$ 2,4-D following bloom applications. By 4 WAT the deleterious effects of prebloom applications were more apparent and the linear decline in flower number was similar to that with bloom applications.

Hemphill and Montgomery (1981) found that $2.1 \mathrm{~g} \cdot \mathrm{ha}^{-1}$ 2,4-D increased pepper yield because of increased branching and flowering. Bennet (1989) reported early flowering of tomato plants treated with low concentrations of 2,4-D, with retardation of flowering and abnormal flowers at high concentrations. This is consistent with the biphasic nature of auxins. At low concentrations, auxins can promote growth by cell elongation and division, whereas, at higher concentrations, growth inhibition and abnormalities occur, with subsequent chlorosis and necrosis (Grossman, 1998).

Fewer than three fruits per plant had been set, even on nontreated plants, 2 weeks after prebloom or bloom applications (Fig. 7D). Whereas a slight but significant decrease in fruit number occurred with increasing rates of 2,4-D applied prebloom, no difference in fruit number was obtained with bloom applica- 


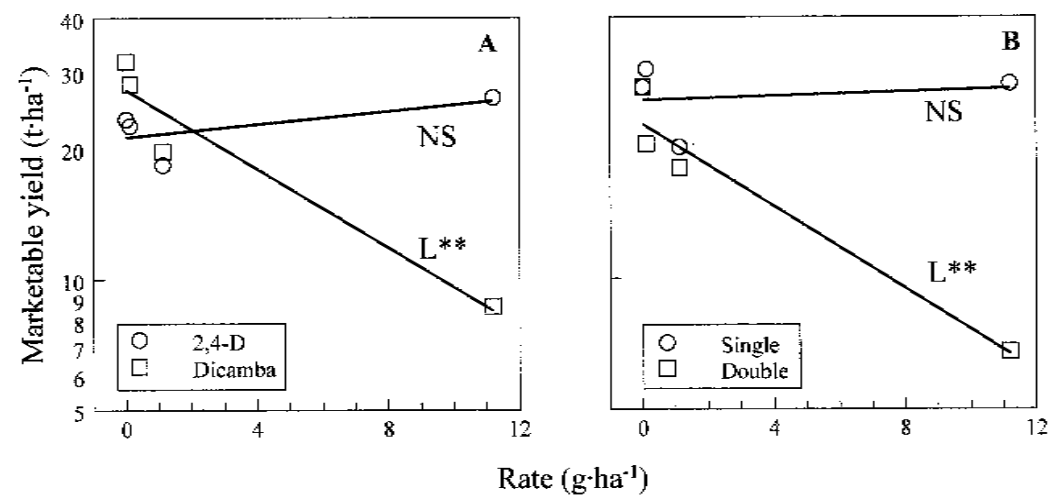

Fig. 5. Marketable pepper yield in response to (A) herbicide and rate averaged over number of applications, and (B) rate and number of herbicide applications averaged over herbicide (Expt. 2). ${ }^{\text {ss, }{ }^{* *} \text { Nonsignificant and }}$ significant at $P \leq 0.01$, respectively, for linear (L) effect. "Single" indicates one prebloom application and "double" indicates two sequential applications, prebloom and postbloom. Yield was log-transformed to correct for heterogeneity of variance.

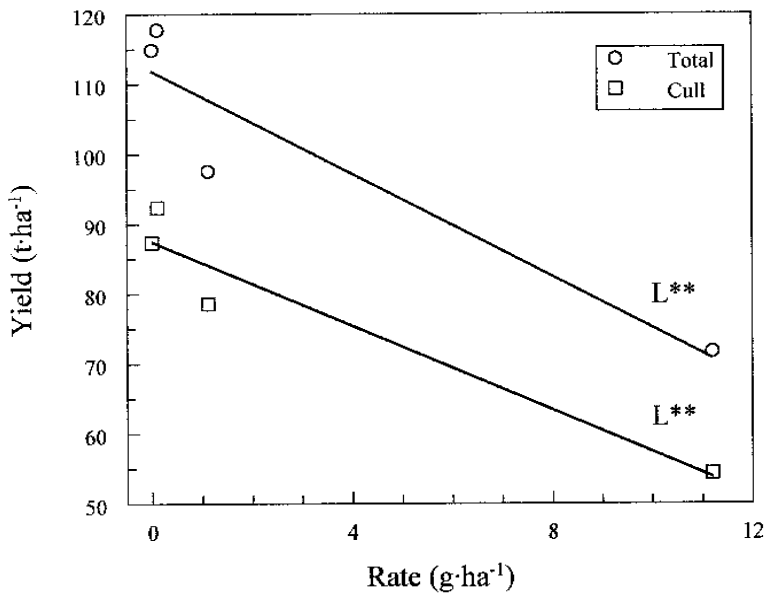

Fig. 6. Cull and total yields of pepper in response to herbicide rate (Expt. 2). Means were pooled across herbicides and number of applications. ${ }^{* *}$ Significant at $P \leq 0.01$ for linear (L) effect. Cull yield logtransformed to correct for heterogeneity of variance.
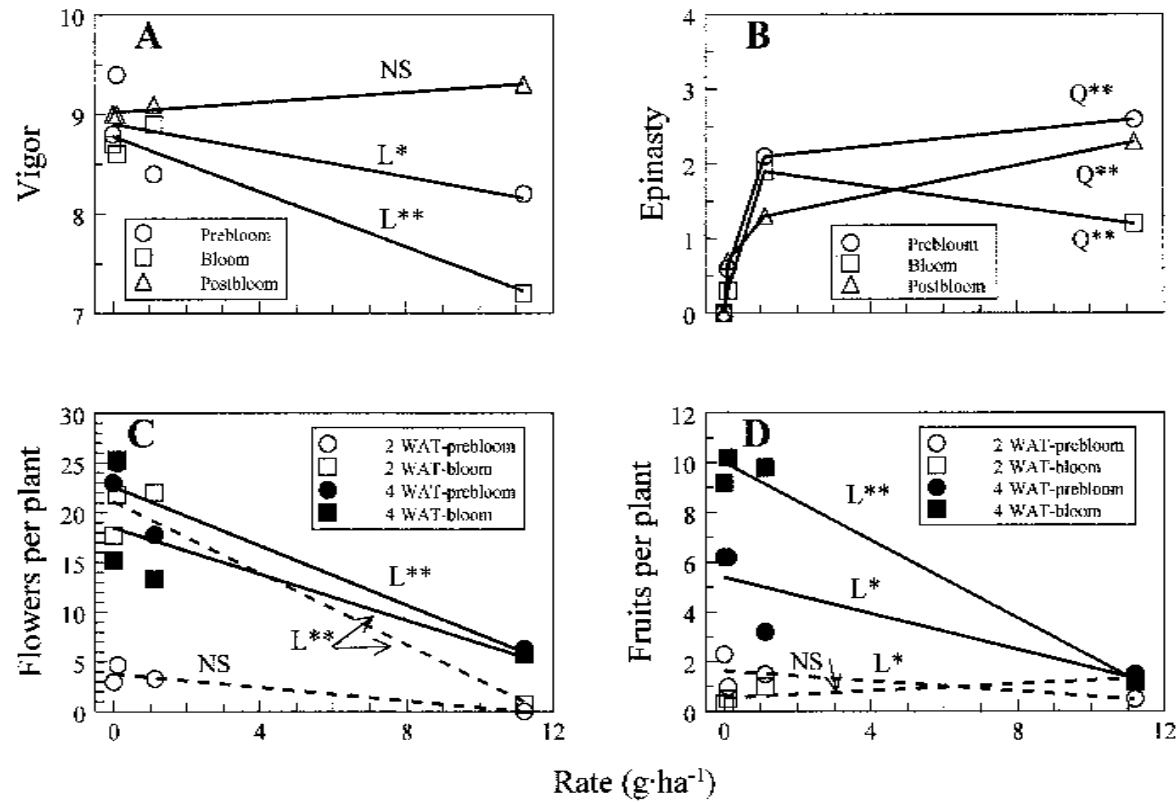

Fig. 7. Effects of sublethal rates of 2,4-D and stage of development at application on (A) pepper plant vigor, (B) foliar epinasty, (C) flower number, and (D) fruit number (Expt. 3). ${ }^{\mathrm{Ns},{ }^{*}, * *}$ Nonsignificant and significant at $P \leq 0.05$ and $P \leq 0.01$, respectively, for linear (L) or quadratic (Q) effects. Vigor was rated on a scale from 0 to 10 , with 10 indicating highest vigor and 0 indicating dead plants. A leaf epinasty rating of 10 indicated severe epinasty and 0 indicated none. tions. For both developmental stages, fruit number decreased linearly with increasing rates of 2,4-D (Fig. 7D).

For marketable and total yields, interaction between rate and developmental stage was significant $(P<0.05)$. Although both were unaffected by 2,4-D when applied postbloom, with prebloom and bloom applications there were pronounced linear decreases as 2,4-D rates increased to $11.2 \mathrm{~g} \cdot \mathrm{ha}^{-1}$ (Fig. $8 \mathrm{~A}$ and C). Comparisons between marketable and total yields with prebloom and bloom applications revealed no significant difference due to developmental stage at the time of application (data not shown). Yield of cull fruit declined linearly with increasing rates of prebloom 2,4$\mathrm{D}$ applications. However, no change in yield of cull fruit was obtained with bloom applications, and cull fruits increased with postbloom applications of 2,4-D (Fig. 8B).

Chlorosis and necrosis, which result from cyanide accumulation (Grossman, 1998), occurred only with $112 \mathrm{~g} \cdot \mathrm{ha}^{-1}$, but not with lower rates. This indicates that the primary negative impact of the lower rates of 2,4-D and dicamba on pepper appears to be flower abscission, leading to reduced fruit set and yield. Epinasty and reduced plant vigor had less influence on marketable yield than did flower abscission in this study with pepper as well as in a previous study, with tomato (Gilreath et al., unpublished). Since the harvested product of pepper is the fruit, the hormonal effects on flowers and thus fruit yield are critical. Apparent stimulation of flowering at low herbicide concentrations was nonsignificant and did not translate into significantly higher yields. Low rates also had less effect on plant vigor and epinasty. As rates of dicamba and 2,4-D increased with prebloom or bloom applications or with multiple applications, increased flower abscission and reduced fruit set occurred, which were detrimental to cropyield. However, when application occurred postbloom, after most of the crop was set, sublethal rates of $112 \mathrm{~g} \cdot \mathrm{ha}^{-1}$ or less did not significantly affect marketable pepper yield.

\section{Literature Cited}

Abeles, F.B. 1968. Herbicide-induced ethylene production: Role of the gas in sublethal doses of 2,4D. Weed Sci. 16:498-500.

Bennet, R.J. 1989. The effects of 2,4-D iso-octyl ester/ioxynil herbicide in the liquid and vapour phases on the growth of tomato (Lycopersicon esculentum Mill.) plants. S. Afr. J. Plant Soil 6:24-31.

Breeze, V.G. 1988. Effects of low concentrations of vapour of the phenoxyalkanoic herbicide 2,4-Dbutyl on growth of tomato plants. Pesticide Sci. 22:251-261.

Breeze, V.G. and E. van Rensburg. 1991. Vapour of the herbicide 2,4-D is toxic to tomato and lettuce plants. Environ. Pollution 72:259-267.

Breeze, V.G. and E. van Rensburg. 1992. Uptake of the herbicide $\left[{ }^{14} \mathrm{C}\right] 2,4-\mathrm{D}$ iso-octyl in the vapour phase by tomato and lettuce plants and some effects on growth and phytotoxicity. Ann. Appl. Biol. 120:493-500.

Breeze, V.G. and C.J. West. 1987. Long- and shortterm effects of vapour of the herbicide 2,4-D butyl on the growth of tomato plants. Weed Res. 27:13-21. 

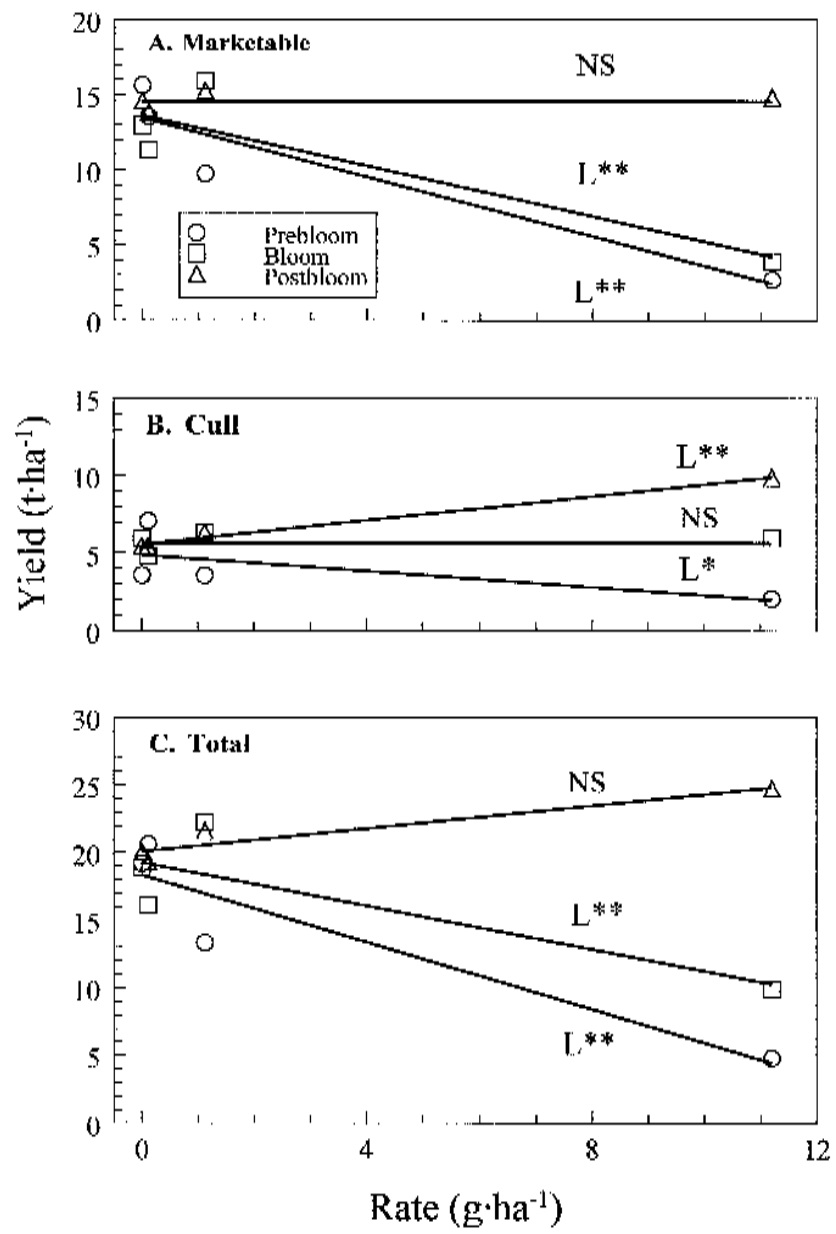

Fig. 8. Effect of sublethal rates of 2,4-D and stage of development on (A) marketable yield, (B) cull yield, and (C) total yield of pepper (Expt. 3). Ns, *,**Nonsignificant and significant at $P \leq 0.01$ for linear (L) effects. Note that vertical scales differ in $(\mathbf{A}),(\mathbf{B})$, and $(\mathbf{C})$.
Carlin, A.F., T.T. Huang, and J.L. Weigle. 1971. Influence of sublethal concentrations of 2,4-D on tomatoes and tomato juice. J. Amer. Soc. Hort. Sci. 96:138-141.

Grossman, K. 1998. Quinclorac belongs to a new class of highly selective auxin herbicides. Weed Sci. 46:707-716.

Hemphill, D.D. and M.L. Montgomery. 1981. Response of vegetable crops to sublethal application of 2,4-D. Weed Sci. 29:632-635.

Jordan, T.N. and R.R. Romanowski. 1974. Comparison of dicamba and 2,4-D injury to fieldgrown tomatoes. HortScience 9:74-75.

Orsenigo, J.R. 1964. Some vegetable responses to chlorophenoxy herbicide exposure. Proc. Fla. State Hort. Soc. 77:230-232.

Robbins, W.A. and W.S. Taylor. 1957. Injury to canning tomatoes caused by 2,4-D. Proc. Amer. Soc. Hort. Sci. 70:373-378.

SAS Institute. 1988. SAS/STAT user's guide, release 6.03 ed., SAS Inst., Cary, N.C.

Sherwood, C.H., J.L. Weigle, and E.L. Denison. 1970.2,4-D as an air pollutant: Effects on growth of representative horticultural plants. HortScience 5:211-213.

Simons, J.N. and B.J. Pariente. 1982. Persistence of oil-soluble amine-type 2,4-D in south Florida Proc. Fla. State Hort. Soc. 95:344-347.

Snedecor, G.W. and W.G. Cochran. 1980. Statistical methods. The Iowa State Univ. Press, Ames.

Tittle, F.L., J.S. Goudey, and M.S. Spencer. 1990. Effect of 2,4-dichlorophenoxyacetic acid on endogenous cyanide, $\beta$-cyanoalanine synthase activity, and ethylene evolution in seedlings of soybean and barley. Plant Physiol. 94:11431148 .

Wall, D.A. 1994. Potato (Solanum tuberosum) response to simulated drift of dicamba, clopyralid, and tribenuron. Weed Sci. 42:110-114.

Weigle, J.L., E.L. Denison, and C.H. Sherwood. 1970. 2,4-D as an air pollutant: Effects on market quality of several horticultural crops. HortScience 5:213-214. 